\title{
Methodology for mapping the average transaction prices of residential premises using GIS
}

\begin{abstract}
Geographic information systems (GIS) and their tools support the process of real estate trading. Of key importance is the ability to visualise information about real estate in the form of maps of average real estate transaction prices. The following study presents a methodology for mapping average real estate transaction prices using GIS. The map development process comprised three main stages. In the first stage, the input data was processed and statistically analysed. Official data came from the Register of Real Estate Prices and Values, and open data from the National Register of Boundaries. The second stage involved the visualization of the data in the form of maps of average apartment prices using the cartographic methods of choropleth maps and diagrams. The commercial tool ArcMap 10.3 and the free Quantum GIS software were used in the design of the maps of average real estate transaction prices, to check the options for using these types of programs. As a result, eight maps were designed presenting the average transaction prices for residential properties in the Warsaw district of Ursynów in 2015. The final stage was the analysis of the designed maps. The influence of the selection of the reference units on the visualization content, and the impact of combining cartographic presentation methods on the complexity of the presentation of real estate information, were also analysed.
\end{abstract}

Keywords: real estate valuation, geographic information systems (GIS), map of average real estate transaction prices, cartographic presentation methods

\section{Introduction}

Using geographic information systems (GIS) for real estate trading is possible due to their spatial character, based on geometry and location in the geographical space. This means that all real estate can be entered into the coordinate system. Information about real estate transaction prices is also of a spatial nature. This is due to the fact that real estate transaction prices are linked to the size of the space and the topological relationships between particular properties. This enables information about the price of a property to be related to the geographic space and its visualization in the form of maps using GIS (P. Cichociński 2007).

This article presents a method for the development of maps of average transaction prices of residential premises in the Warsaw district of Ursynów in 2015. Official data for the development of the maps came from the Register of
Real Estate Prices and Values (RREPV), and open data (available without charge) from the National Register of Boundaries (NRB). Data on average real estate prices is presented using a five-class division, based on two reference units - cadastral districts and the units of the Municipal Information System (MIS).

\section{Using GIS for real estate trading}

Geographic information systems are used in real estate valuation to conduct analyses, visualizations and real estate market models (A. Podor 2010). GIS enables the integration of different types of spatial and attribute-based information (D. Gotlib et al. 2007), which is important in terms of allowing the presentation of a number of features of the real estate market. This information is then used in decision-making processes relating to the real estate market (K.H. Donlon 2007). GIS includes tools to 
improve searching for, and the effective selection of, information on real estate. The use of GIS for real estate trading is also important in enabling the efficient visualization of information. The presentation of information in the form of a map supports spatial analysis and decision-making processes related to real estate (D. Gotlib et al. 2007), such as strategic planning and the assessment of the success of real estate investments (A. Podor 2010). GIS users are able to assess a property and its location using basic measurement tools (e.g. plot area, distance between the property and selected points) and advanced tools for spatial and attribute-based analysis. Furthermore, GIS enables information to be added through the integration of data from other spatial databases (D.S. Bible and C. Hsieh 1996).

An example of a geographic information system developed to improve the management of real estate is AraromiPhase IV. This system was developed for the Oyo area in Nigeria. It facilitates the implementation of spatial queries, the development and update of maps of the real estate market, and the creation of buffer zones (S.S. Olaniyi et al. 2006). Another example is the German BORISplus system (Bodenrichtwertinformationssystem), developed for the North Rhine-Westphalia area and used by the office responsible for real estate valuation. One of its advantages is its availability online (https:// www.boris.nrw.de/borisplus/?lang=de). Based on information entered by the user - for example, on a property's location - the system generates a map marking out the properties that meet the criteria defined by the user (B. Czesak 2012).

Another GIS similar to BORISplus is the information system developed for the Kraków district of Żabiniec. Although not available online, compared to BORISplus it produces more accurate geometric representations of properties, generated automatically in the GeoMedia program based on the digitised structure of a basic map (B. Czesak 2012).

\section{Map of average real estate transaction prices}

One of the advantages of presenting information in a map form is the possibility of showing the spatial relationships between structures (J. Bydłosz et al. 2010). Maps showing real estate prices and values are variously defined in the literature. This results from the differences between types of real estate, reference areas used, and types of real estate values (B. Całka and E. Bielecka 2014). Polish law contains a definition of real estate transaction price maps, known as "maps of average land transaction prices". A Decree of the Council of Ministers from 2011 defines a map of average land transaction prices as a kind of thematic cartographic elaboration. This map is created based on the Register of Real Estate Prices and Values, statistical surveys, analyses and reports on the real estate market. The Surveyor General is responsible for producing maps in digital form. The elaboration shows the variation in average transaction prices of real estate across the whole country, taking into account the three-degrees territorial division (Rozporządzenie... 2011).

Maps of real estate value support the realisation of interim goals - the mass valuation of real estate - and improve the control of property value; they help public bodies and the Treasury to determine the value of property, to facilitate the management of real estate and to establish a fair basis for property tax. Furthermore, real estate value maps facilitate the realisation of long-term goals such as obtaining information on real estate values from published information, including online. The information obtained from this type of map can be used to justify planning decisions, investments and activities related to the development of an area (R. Cellmer and J. Kuryj 2011). For the purpose of visualizing the variability of property prices in an area, the reference unit needs to be specified. The reference unit can be a homogeneous pricing zone or an administrative unit (B. Całka and E. Bielecka 2014). The process of determining homogeneous zones is problematic, since it is not regulated by law (R. Cellmer and J. Kuryj 2011). The significant limitations associated with the development of price maps include limited access to information on real estate, gaps in the databases and the large range of prices included in the databases (J. Bydłosz et al. 2010). Maps of real estate value can be developed using basic cartographic methods, such as conventional symbols or choropleth maps (R. Cellmer 2014). The simplest cartographic method to show variation in average real estate prices is the 
choropleth map related to administrative units (B. Całka and E. Bielecka 2014).

The maps of T. Budzynski and I. Karsznia (2014) provide an example of elaborations showing average real estate transaction prices. The maps were developed at a scale of $1: 1,000,000$ for the Mazowieckie Voivodship based on data from the Register of Real Estate Prices and Values (RREPV). In terms of the main problems in developing the maps, the authors indicated the huge variation in real estate transaction prices between different counties and the related difficulties involved in selecting the optimal method of presenting the data, as well as the gaps in the RREPV data. As the authors noted, the type and availability of data influences the effectiveness of visualization in the form of maps, and the efficiency of further analysis (T. Budzyński and I. Karsznia 2014).

\section{Research methodology}

The aim of the research was the design of maps of average transaction prices of residential premises in the Warsaw district of Ursynów in 2015. The design of the maps involved three stages (fig. 1). The first stage was the selection and processing of the input data. The availability

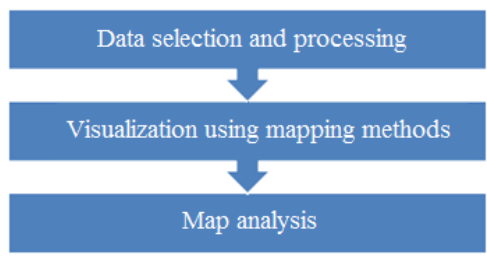

Fig. 1. Diagram of research methodology (source: own elaboration)

and relevance of spatial and non-spatial data was analysed. Two GIS programs - QGIS 2.8.6 and ArcMap 10.3 - were used for data integration and MS Excel 2013 was used to process the data contained in the RREPV. The two GIS programs were used to highlight the possibilities of both commercial and free software. The second stage involved the visualization of the data in the form of a map of average apartment prices using the chosen cartographic presen- tation methods. The design of the maps of average real estate transaction prices began with the integration of the processed data in the ArcMap 10.3 program. The data were then analysed in order to select the appropriate cartographic methods of presentation. It was decided to use the choropleth and diagram methods. The third and final stage of the research was the analysis of the designed maps.

\subsection{Selection and processing of data}

The source of the spatial data needed to develop the maps of average real estate transaction prices in the district of Ursynów was the National Register of Boundaries (NRB) and units of territorial division of the country [1]. From the available vector layers in the QGIS 2.8.6 program, 145 cadastral districts were distinguished in the area of Ursynów, giving the first basic reference units. The NRB boundaries (cadastral districts) were verified on the basis of the reference data contained in the Information System for the Capital Area iGeoMAP [2] and WMS service. Open Street Map data were connected to QGIS 2.8.6 program in the form of WMS and were compared to previously developed vector layer of NRB reference units. The cadastral district boundaries were presented in SIT iGeoMAP, taking into account the positioning of the streets. The boundaries of the received vector layer of NRB units were checked for agreement with the boundaries in OSM and iGeoMAP.

The second, generalised type of reference units were the units defined by the Municipal Information System (MIS), of which there are 14 in the area of Ursynów. The vectorization of the MIS layer involved using information about the boundaries of individual units from the Municipal Road Authority website [3] and data from Open Street Map (OSM) in the form of WMS. The processing of the spatial data resulted in 145 cadastral districts, 47 of which were involved in transactions in 2015, and 14 MIS units, including 10 areas involved in transactions. It should be emphasised that the MIS reference areas are not a direct result of the aggregation of the cadastral districts. The vector layers prepared for both types of reference units were analysed further using the ArcMap 10.3 program. 
The source of data on real estate prices was RREPV. The data covered prices and values of real estate in 2015. In the unprocessed RREPV, the prices and values of individual properties were distinguished on the basis of the cadastral districts in Ursynów. Preliminary data analysis involved verifying the accuracy of the assignment of real estate to particular cadastral districts, based on the address of the property and comparison with Open Street Map (OSM) data. Verification was carried out using the QGIS 2.8.6 program.

The next step was to integrate the data with RREPV and NRB. The source data contained in the RREPV on individual properties refers to points, while the vector data obtained from the NRB and MIS refers to areas. In order to integrate the registers, the data contained in the RREPV was aggregated into NRB units (cadastral districts) and MIS units in MS Excel 2013. Next, the average values of selected statistical measures were calculated for both reference units and collected in a table. The prepared tables and designed maps also included the number of transactions in each reference unit and the type of real estate market, divided into primary and secondary markets. The selection of statistical characteristics was based on the methodology proposed by T. Budzyński and I. Karsznia (2014) for mapping the average transaction prices for the Mazowieckie Voivodship. The statistical functions in Microsoft Excel 2013 were used for this purpose. The characteristics were calculated for the primary and secondary real estate markets. They referred to the average transaction prices of residential premises in the separate cadastral districts and MIS units of Ursynów, expressed in złotys per square metre. For all NRB units (cadastral districts) and MIS units, the following statistical measures were calculated:

- arithmetic average

- median

- minimum price

- maximum price

- first quartile

- third quartile

- standard deviation.

Due to its lower sensitivity to outliers compared to the arithmetic mean (G. Trzpiot 2013), the median was chosen as the statistical characteristic used to present price volatility.

\subsection{Cartographic visualization}

The maps of average transaction prices of residential premises were prepared in the ArcMap 10.3 program. The choropleth method was used to design maps presenting the median prices of residential premises. Further layers were added to the program with the NRB reference units (cadastral districts) and the MIS units. To enrich the content of the maps, the metro line and the main streets and roads in Ursynów were included. These structures were also shown due to their direct impact on real estate value. For each type of market, data on the median real estate prices was added using the Join function. Charts of the median real estate prices were then developed in MS Excel 2013 (figures $2^{1}$ and $3^{2}$ ). The charts were developed to compare the median real estate values in złotys per square metre for the primary and secondary markets, with the two types of reference units distinguished. Showing the joint real estate values for the two markets made it possible to use the same choropleth map class intervals for these markets, as well as for both types of reference units. Another fundamental aim behind the design of the maps was their efficient visual analysis and the ability to compare price variability presented in relation to the two types of reference areas. The developed charts of the median real estate prices are presented in figures 2 and 3 .

The analysis of the values in the charts and tables led to a proposal of the class intervals for the choropleth map. The number and range of class intervals ensured the efficient reading of information from the map. In the five-class division, the boundaries of middle class have the same intervals and the boundaries of the extreme class are adjusted to the highest and lowest median values of real estate prices in the set. The proposed class limits in the fiveclass division are presented in figure 4.

Finally, four maps were developed to show the median real estate prices using choropleth maps, divided into the primary and secondary

\footnotetext{
1 The total number of median values results from the fact that $5 \mathrm{MIS}$ units were involved in transactions on the primary market, and 10 units on the secondary market.

2 The total number of median values results from the fact that 46 NRB unit was involved in transactions on the primary market, and 10 units on the secondary market.
} 


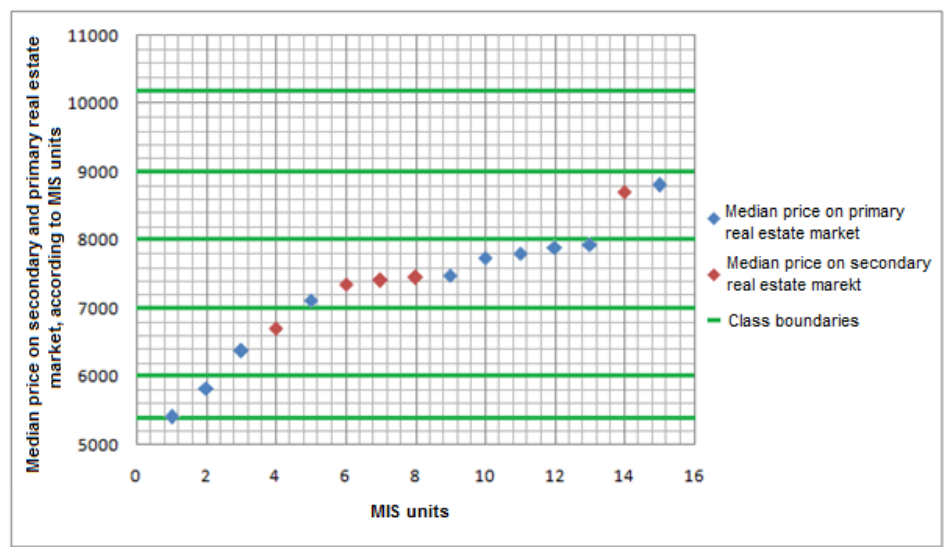

Fig. 2. Median transaction prices of residential premises in złotys per square metre on the primary and secondary markets, according to MIS units (source: own elaboration)

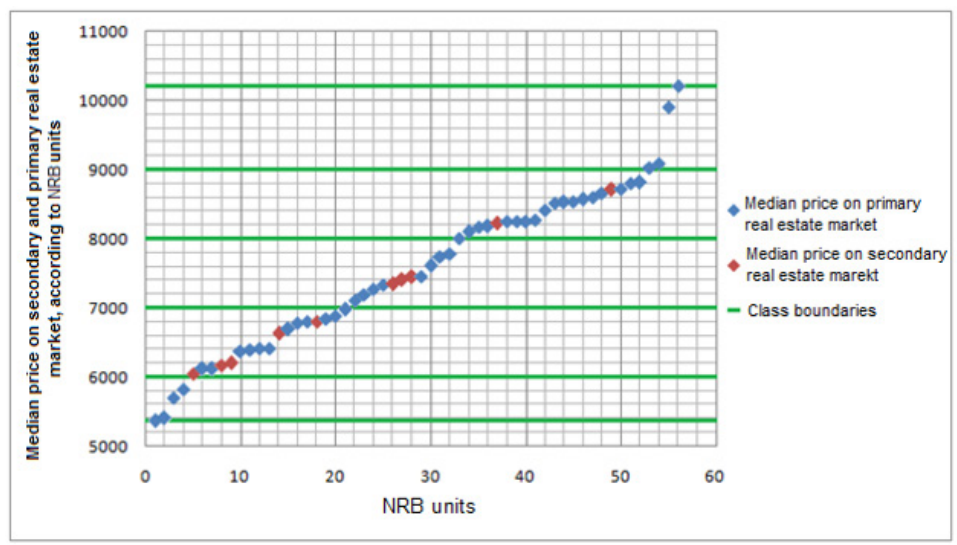

Fig. 3. Median transaction prices of residential premises in złotys per square metre on the primary and secondary markets, according to NRB units (source: own elaboration)

markets (figs. 5-8). Maps were developed for the two types of real estate market and for the two types of reference area, using the fiveclass generalization. The aim was to enable the comparison of the variability in median real estate prices, depending on the type of real estate market analysed, for both types of reference areas. The elaboration included:

- a map of average real estate transaction prices on the secondary market according to MIS units (fig. 5),

- a map of average real estate transaction prices on the secondary market according to cadastral districts (fig. 6),

\section{Median prices}

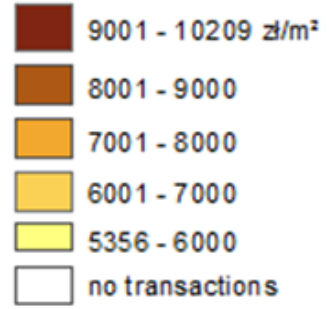

Fig. 4. Classification legend (source: own elaboration) 


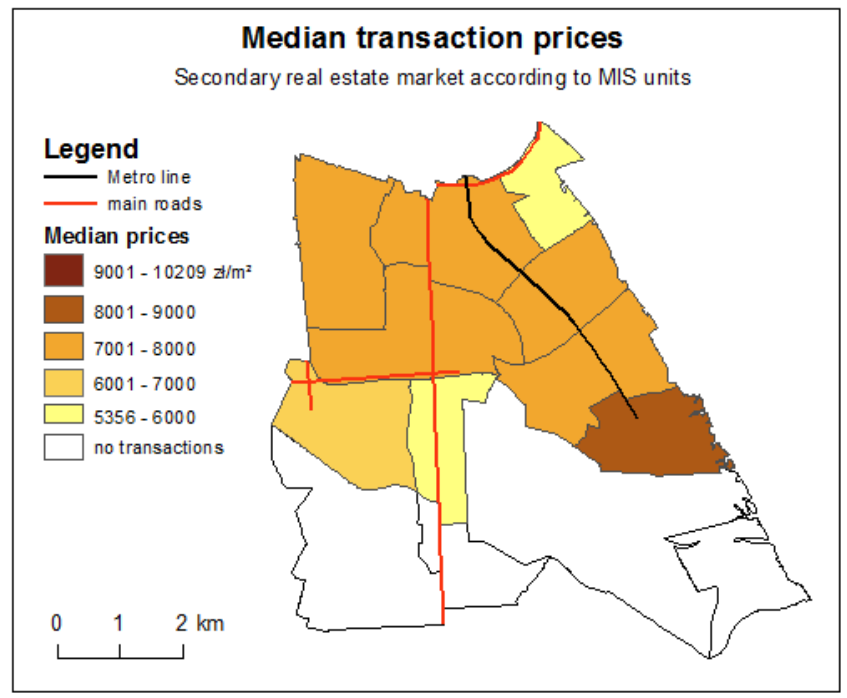

Fig. 5. Average prices of residential premises on the secondary real estate market in Ursynów, according to MIS units

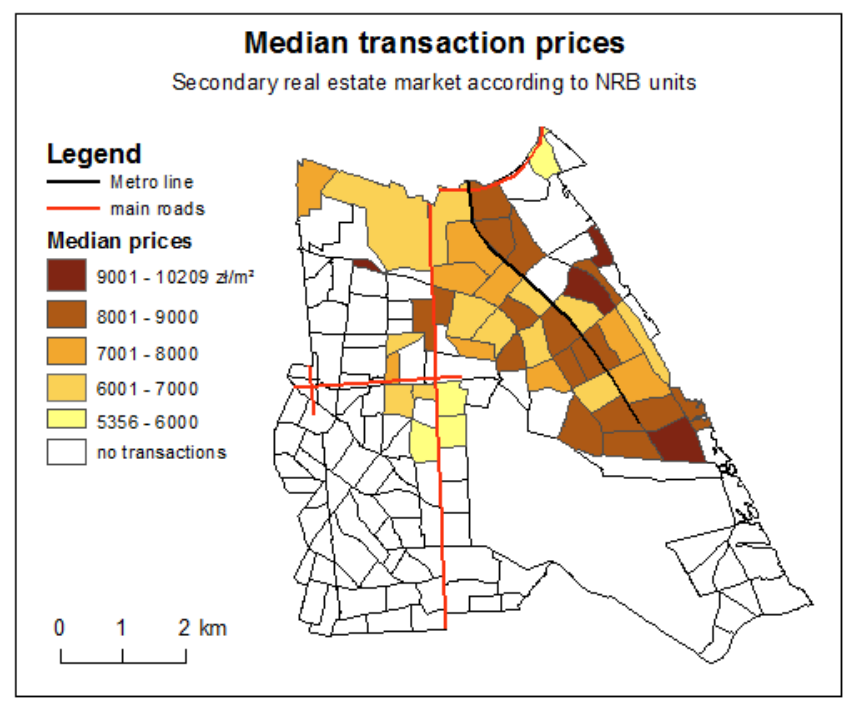

Fig. 6. Average prices of residential premises on the secondary real estate market in Ursynów, according to cadastral districts

- a map of average real estate transaction prices on the primary market according to MIS units (fig. 7),

- a map of average real estate transaction prices on the primary market according to cadastral districts (fig. 8).
In order to provide more comprehensive and synthetic information about real estate, maps combining methods of cartographic data presentation were also developed. Diagrams illustrating the number of transactions on the primary and secondary markets were superim- 


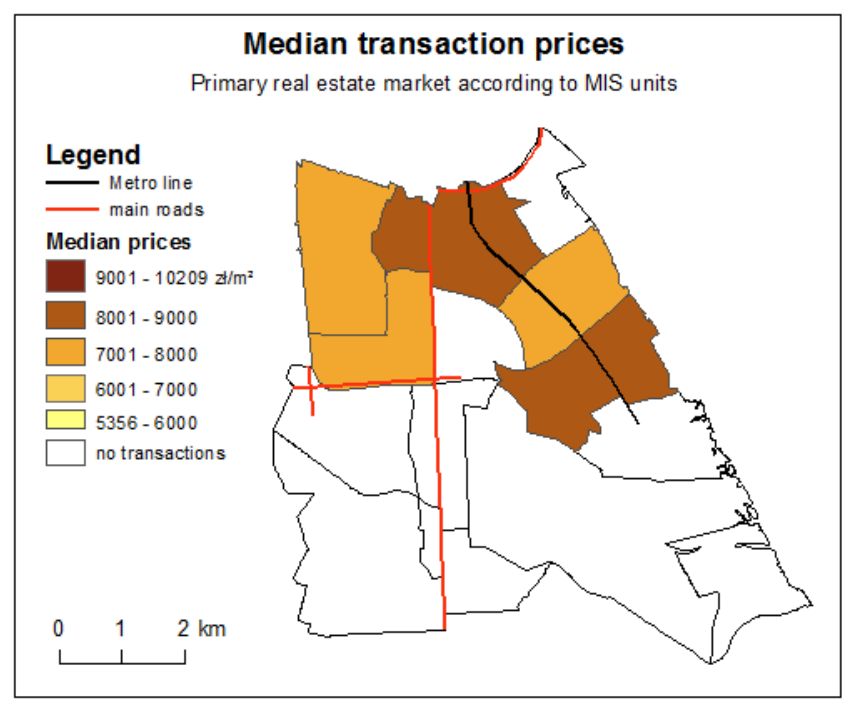

Fig. 7. Average prices of residential premises on the primary real estate market in Ursynów, according to MIS units

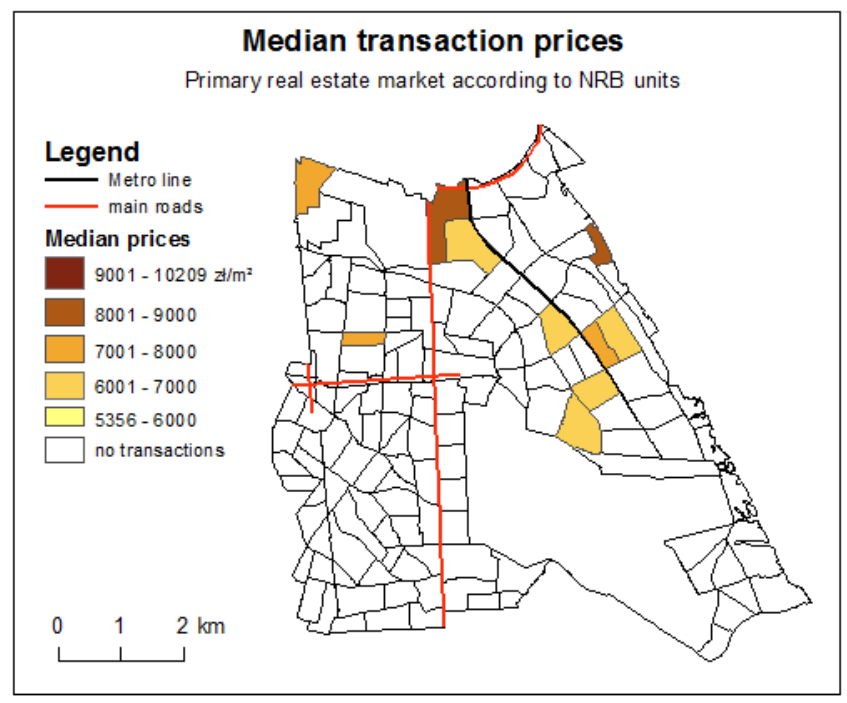

Fig. 8. Average prices of residential premises on the primary real estate market in Ursynów, according to cadastral districts

posed on the layers presenting the choropleth map of median real estate prices in individual reference units (figs. 9-12). As a result, four maps were designed:

- a map of the number of transactions on the primary and secondary markets in relation to the median of the primary real estate market, according to MIS units (fig. 9),

- a map of the number of transactions on the primary and secondary markets in relation to the median of the primary real estate market, according to cadastral districts (fig. 10), 


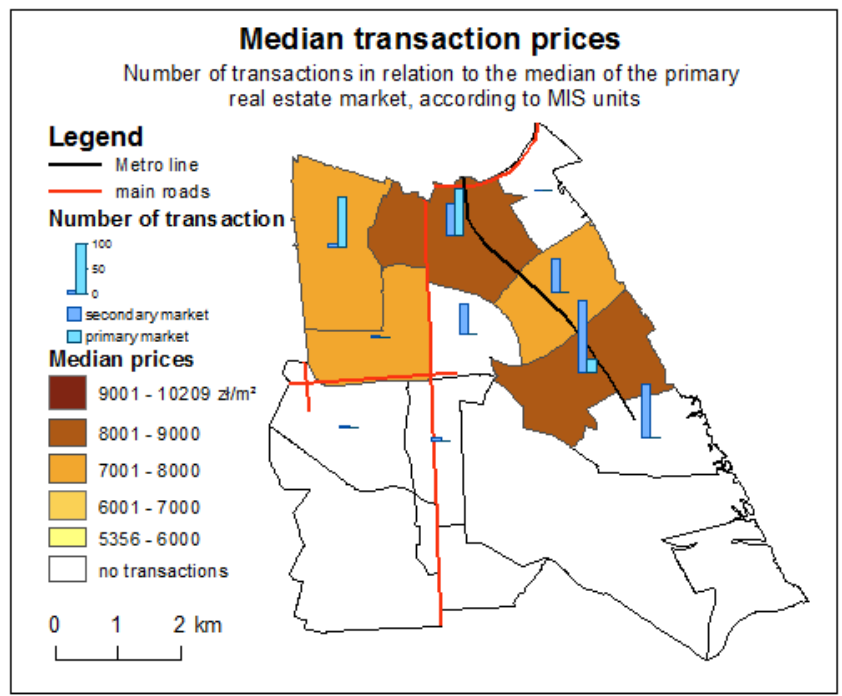

Fig. 9. Number of transactions on the primary and secondary residential real estate markets in Ursynów in relation to the median of the primary real estate market, according to MIS units

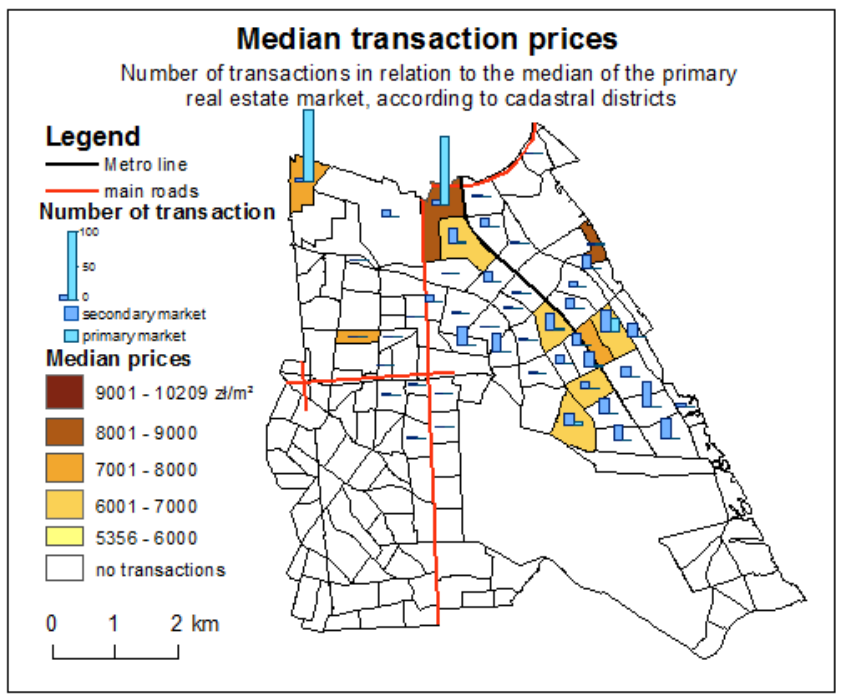

Fig. 10. Number of transactions on the primary and secondary residential real estate markets in Ursynów in relation to the median of the primary real estate market, according to cadastral districts

- a map of the number of transactions on the primary and secondary markets in relation to the median of the secondary real estate market, according to MIS units (fig. 11),
- a map of the number of transactions on the primary and secondary markets in relation to the median of the secondary real estate market, according to cadastral districts (fig. 12). 


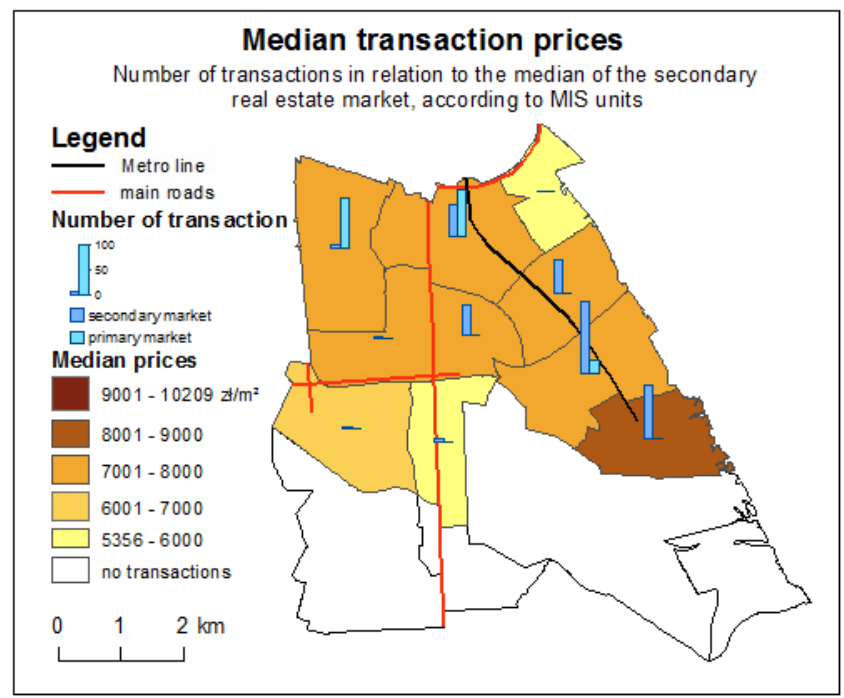

Fig. 11. Number of transactions on the primary and secondary residential real estate markets in Ursynów in relation to the median of the secondary real estate market, according to MIS units

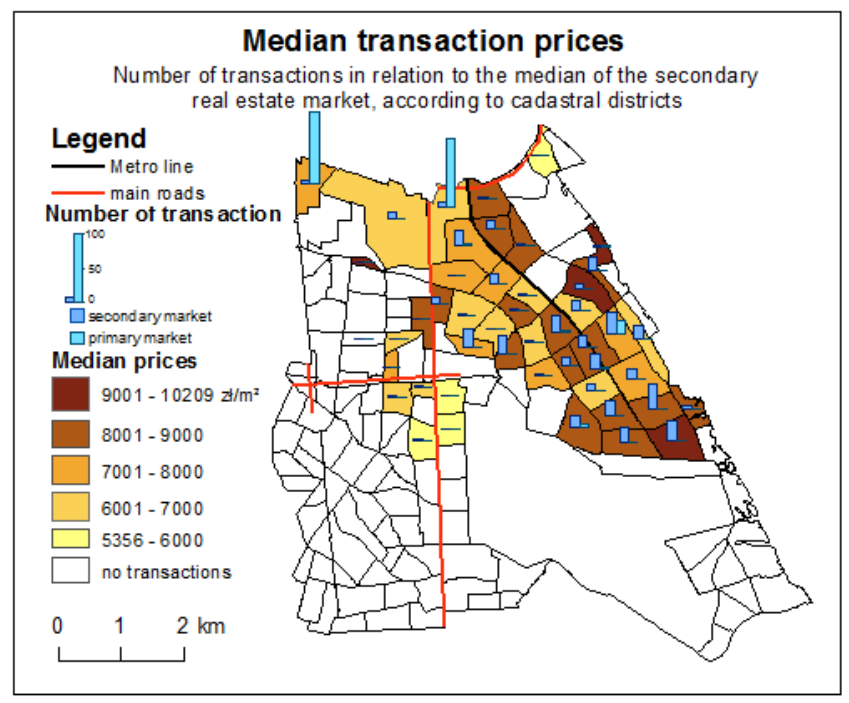

Fig. 12. Number of transactions on the primary and secondary residential real estate markets in Ursynów in relation to the median of the secondary real estate market, according to cadastral districts

\subsection{Analysis of findings. Conclusions}

According to J. Bydłosz et al. (2010), the main problems involved in developing maps of average real estate transaction prices are the availability of data, the lack of information in databases and the range of property prices resulting from over- or undervaluing by the parties to the transactions. The development of maps of the median prices of residential 
premises in Ursynów in 2015 confirmed the methodological aspects of mapping property prices mentioned by these authors. The development of the maps was only made possible by combining spatial and non-spatial data. The data from the Register of Real Estate Prices and Values (RREPV) showed the deficiencies that may arise, for example, in relation to the length of the research period (only 2015). The lack of information meant that the developed maps include reference areas that were not involved in transactions. The analysis of the charts of median real estate prices (figs. 2 and 3 ) confirmed the wide range of prices.

The mapping of the median prices of residential premises in Ursynów in 2015 revealed how the choice of reference unit affects the presented phenomenon. The use of a larger reference unit apparently increases the impression of completeness of the data, which may be a way to overcome the problem of the content of information in real estate databases. However, adopting a larger reference unit results in the generalization of information about the variability of the phenomenon presented on the map.

The five-class generalization adopted on the maps was adjusted to the distribution of the median prices of real estate, taking into account the tabulation of all median prices and developed charts (figs. 2 and 3 ). This classification contributes to the quick and easy interpretation of the variability of real estate prices.

Another aim of the research was to determine the effect of combining of the cartographic

\section{Literature}

Bible D.S., Hsieh C., 1996, Application of geografic information systems for the analysis of apartment rents. "The Journal of Real Estate Research" Vol. 12, no 1, pp. 79-88.

Budzyński T., Karsznia I., 2014, The ap of average land transaction prices - a new Polish cartographic product. "Science and Technologies in Geology, Exploration and Mining Conference Proceedings" T. 3, pp. 973-980.

Bydłosz J., Cichociński P., Parzych P., 2010, Możliwości pokonania ograniczeń rejestru cen i wartości nieruchomości za pomocą narzędzi GIS. „Studia Informatica" Vol. 31, nr 2B (90), pp. 229-244.

Całka B., Bielecka E., 2014, Mapa średnich cen transakcyjnych mieszkań: studium przypadku pierwotnego rynku nieruchomości w Siedlcach. „Roczniki Geomatyki” T. 12, nr 4 (66), pp. 379-387. presentation methods of data on the complexity of real presentation. The analysis of the designed maps revealed that the combination of cartographic presentation methods has a beneficial effect on the scope of information that can be extracted from the map. For maps developed using only the choropleth method, only a general analysis of the distribution of median prices in the area of Ursynów can be carried out, and the influence of neighbouring areas can be considered. Applying additional layers to the map allows the analysis of price changes depending on the metro lines and the main streets and roads. Adding the number of transactions of the primary and secondary markets as bar graph to a developed choropleth map (figs. 9-12) gives the possibility of additional analyses. The reader may then conclude whether the real estate price in individual reference units affected the number of transactions, and which market (primary or secondary) saw more transactions. In addition, it is possible to ascertain which reference area saw the greatest or smallest number of transactions in 2015.

In the presented research concerning the design of maps of average real estate transaction prices, the official and open data, as well as spatial and attribute-based data have been integrated. The analysis of the results has shown that it is advisable to enrich databases by adding information from external open sources, as well as using different cartographic methods for the effective visualization of data on the valuation of real estate.

Cellmer R., 2014, Modelowanie przestrzenne w procesie opracowywania map wartości gruntów. Olsztyn: Wydawnictwo Uniwersytetu Warmińsko-Mazurskiego.

Cellmer R., Kuryj J., 2011, Określenie stref o podobnej cenności gruntów z wykorzystaniem metod geostatystycznych. „Studia i Materiały Towarzystwa Naukowego Nieruchomości" T. 19, nr 3, pp. 7-19.

Cichociński P., 2007, Zastosowanie metod kartograficznych i geostatystycznych do wstępnej analizy rynku nieruchomości. „Studia i Materiały Towarzystwa Naukowego Nieruchomości” T. 15, nr 3-4, pp. 155-166.

Czesak B., 2012, Koncepcja systemu informacji geograficznej wspomagającego wycenę nieruchomości w nawiązaniu do niemieckiego systemu 
BORISplus. „Infrastruktura i Ekologia Terenów Wiejskich" Nr 3/II, pp. 37-47.

Donlon K.H., 2007, Using GIS to improve the Services of the Real Estate Company. "Papers in Resource Analysis" Vol. 10.

Gotlib D., Iwaniak A., Olszewski R., 2007, GIS. Obszary zastosowań. Warszawa: Wydawnictwo Naukowe PWN.

Olaniyi S.S., Udoh E.A., Oyedare B.A., Adegoke Q., 2006, Application of GIS in estate management (A case of study of Araromi Phase IV, Oyo, Nigeria). XIII FIG Congress, Germany 8-13.10.

Podor A., Nyiri J., 2010, GIS application in real estate investment. "Scientific Journal of Riga Technical University. Economics and Business. Economy: Theory and Practice" Vol. 20, pp. 94-99.
Rozporządzenie Rady Ministrów z dnia 3 października 2011 r. w sprawie rodzajów kartograficznych opracowań tematycznych i specjalnych. „Dziennik Ustaw" 2011, nr 222, poz. 1328.

Trzpiot G., 2013, Wybrane statystyki odporne. „Studia Ekonomiczne" Nr 152, pp. 163-173.

\section{Internet sources}

[1] http://codgik.gov.pl/index.php/darmowe-dane/prg. html

[2] http://www.igeomap.um.warszawa.pl/iGeoMap/ Data/Warszawa/Ursynow.html

[3] https://zdm.waw.pl/miejski-system-informacji/obszary-msi/dzielnica-ursynow 